\title{
Restorative Justice in the Republic of Macedonia and the Possibility of Its Application in Juvenile Delinquency with Special Emphasis on the Work of the Mediator, as a European Tendence
}

\author{
Qebir Avziu \\ State University of Tetova, Macedonia, Faculty of Law \\ qebiravziu@gmail.com \\ Afrim Osmani, PhD \\ State University of Tetova, Macedonia, Faculty of Law
}

Doi:10.5901/ajis.2015.v4n2s1p162

\begin{abstract}
This paper aims to demonstrate and explain the notion, meaning and concept of restorative justice and the possibility of its application in juvenile delinquency. In fact here we will discuss the benefits and social progress that provides this law concept. The essence of restorative justice is that the society does not respond against the offender with a sentence, but its tendency is to find the way to reconcile and compensate the damage. So, according to this concept of law the society don't retaliate the offender but finds a way and manner for the offender to reimburse and repay the consequences of his action and thereafter to reconcile with the victim. This law concept emerged three decades ago, but has not found wide application in practice yet and is not very popular. Therefore, the restorative justice is mostly understood as a concept, as a movement or a reaction model of the society after the criminal offense. First of all, not only the perpetrator and the victim are getting engaged in the resolving of the conflict, but the community also, because of the criminal act committed, directly or indirectly are affected other members of society. So in these cases, the community is very interested to solve the conflict between the offender and the victim by peaceful means in order the community to be satisfied. In a few words, the purpose of this right is the modern society to relinquish the traditional concept of punishment and revenge against the offenders and the introduction of new rules of informal (extrajudicial) settlement of criminal case, where the victim and the offender are the only one who discuss the damage compensation to the victim and reintegration of the offender in society.
\end{abstract}

\section{Introduction}

Certainly the notion restorative justice is a new term and sounds quite unknown to most readers and the lawyers. This type of right has actually begun to infiltrate in the field of justice too late, two decades ago. So today, in all democratic countries, when reforms are introduced in the field of criminal law and criminology, especially when it comes to minors, the benefits that the restorative justice offers must be taken into consideration. Therefore, the law on Juvenile Justice is based on four important postulates, where one of these is the notion of restorative justice. (Action plan on the implementation of the Law on Juvenile Rights, Ministry of Justice, 2004). Because of the echo and progressive impact the restorative justice has, its rules has been introduced in almost all democratic countries and this model of extrajudicial conflict resolution, has become a practice that is growing, especially when it comes to minors. Today in many seminars and congresses, the restorative justice is a common topic, offering the most rational models for resolving the criminal and civil lawsuits. Therefore, the resurgence and development of restorative justice, is estimated rightly as one of the greatest achievements of contemporary criminal field and criminal policy in general. (Walgrave, L., (2006), Restorative justice and the Law: socio-ethnical and juridical foundation for a system approach).

\section{The Concept and Meaning of Restorative Justice}

The notion of restorative justice for the first time was used by Albert Eglash (1977), who divides the penal science and reaction against criminality into three parts:

- Retributive justice (based on punishment system)

- Distributive justice (based on therapeutic treatment of perpetrators) 
- Restorative justice (based on damage compensation and reconciliation of conflicting parties). (Ćopić, S., (2002), "Pojam i osnovni principi restorativne pravde", Temida journal, Beograd, p.14.) Besides him, the restorative justice has been also implemented by Mark Umber and Russ Immarigeon (US and Canada) whose intention was to build specific programs that would enable the reconciliation of the victim with the offender. These reconciliation programs were implemented for the first time in Ontario and for its implementation was required the engagement of a negotiator or a mediator. Restorative justice means informal (extrajudicial) way of resolution of conflicts between the offender and the victim. The essence of this right first of all requires from the offender and the victim to agree or find a common way without initializing proceedings. In other words, the restorative justice excludes the punishment of the offender as a primary aim and is based on damage compensation. This means that the restorative justice excludes its retributive character, instead offers a mutual consent. According to the meaning of this right, the society is not interested to punish the offender and retaliate at all costs for the offense he has caused in society, (common law), but focuses on the reconciliation and compensation of damage.So, the restorative justice has a special reaction (mild) of the society against offenders, trying to find a way to reconcile the offender and the victim. First of all, the restorative justice is a right that provides models for the dispute that has arisen between the offender and the victim, not to be solved formally, before the legal court officials and through judicial procedures which result in multiple procedural confusion, time consumption, nervous breakdown and in the end no one is happy, everyone is outraged. Under the concept of restorative justice, when in society is committed an offence, not only the victim is affected, but also the society, because in case of severe criminal offence, all the society is being traumatized and it's an indirect victim of legal order disturbance. In this case, the society cannot remain indifferent, but it also participates in conflict solutions. So, the restorative justice represents a triangle where the informal process takes place between the victim, offender and society. This implies the active engagement of all those concerned (victim, offender and society) who are interested in finding an optimal and more rational way for solving the problems. So according to this justice (restorative justice), priority should always be given to informal or extrajudicial intervention, which means involvement of community where the crime has been committed, instead of the court. Today the application and implementation of restorative justice is suggested by many international standards who recommend the national states to develop and compile programs for the implementation of restorative justice as much as possible. (UN Resolution, (1985), on the principles and rights of the victim Recommendations of the Council of Europe on the position of the victim P. (85), during criminal proceedings).

In the preamble to the UN resolution on the principles and rights of the victim (1985) states that the restorative justice represents "a reaction to crime by respecting the human dignity and equality, that promotes social harmony during the recovery of the victim, offender and society from the consequences of the offense. Despite this, the restorative justice is not easy to understand, because it supports multidimensional treatment of problem solving, related to crime in society. Forms or models the restorative justice offers are of various kinds: mediation between the victim and the offender (victimoffender mediation), family conversations (family group conferencing), social conversations (community conferencing), peace circle (peacemaking circles), sentencing circle (sentencing circles), panels where the victim speaks to offenders (victims panels that speak to offenders), service in favor of the victim or the community (victim directed and citizen involved community service by the offenders, etc.). It is almost impossible to develop a model which would include all cases of conflicts, therefore this right gives the parties and the community a possibility to spontaneously build a model that is more optimal and that will give more results. But as it can be seen, the aim of restorative justice is always to achieve reconciliation and agreement between the victim and the offender, and at the same time to provide compensation of damage to the victim. In this regard, in order to realize the restorative justice, there should be developed various programs, especially those that provide useful work in the community, programs on the avoidance and eradication of consequences for the victim and society, and the reintegration of offenders in society.

\section{Legal Character, Purposes and Principles of Restorative Justice}

The restorative procedure according to the legal character is an informal procedure because its flow is not based on procedural laws and is not strict as the criminal proceeding is. So this procedure is flexible and very elastic, which is directed towards resolving of the dispute between the parties. The motto of restorative procedure is the active engagement of all those concerned with the offense to solve the problem, including community. Restorative procedure relies on the participation of all conflicting parties, which is really much more efficient compared to formal procedures, because it allows direct communication between those who are affected by the offence. Restorative procedure also means undertaking a wide spectrum of actions or measures that lead towards the eradication of the effect, which is caused by the offense. According to the legal character, the concept of restorative justice is not something that is against 
the common law, but its alternative or its constituent part. (Baćanović, O., (2009), "Restorative justice and the law for the rights of minors, Juvenelia journal, Skopje p.113. So, the restorative justice is not meant to completely replace criminal law and criminal procedure, but it appears only as an alternative or as an opportunity that will be used mostly when offenders are of a minor age. Indeed minors are a special category of society because of their age, so they might make mistakes. Therefore the community understands that everyone can make mistakes during the young age, but again there is hope that these individuals because of their young age, will improve and return in society as individuals who respect and behave in accordance with the rules and norms of society. Therefore, the offenders must be given the chance to improve their mistakes. But, through understanding and compensating the committed mistake and offense. Therefore, today is accepted the idea that the restorative justice should be applied to minors, so the Republic of Macedonia's Juvenile Law, anticipates cases when it comes to restorative justice, especially proceedings in the presence of the negotiator-mediator.The benefit from restorative process lies in the fact that the parties do not just focus on consequences, but also discuss the reasons that have caused the offense. They jointly analyze all the circumstances that are crucial and which have led to the demonstration of the consequence, therefore this process is a constructive and continuous.

\section{About Mediation - Mediator in General}

Following, we will focus on mediation as a typical institution of restorative justice that is provided in the law on minors in the Republic of Macedonia, as extrajudicial procedure. In addition, we will take into account the recommendations of the Council of Ministers no. (99) 19 on mediation in the field of criminology. Whenever a new innovative institution is provided, immediately raises the question what are the benefits of it? The mediation procedure is of a very flexible and participatory character. It provides a comprehensive solution to the conflict by reducing the number of sentences and of course the society's costs while the offender is in jail. During the mediation process, the conflicting parties are very active and self-decisive to the conflict. Therefore, during this procedure the conflicting parties (the victim and the offender) have a very active, constructive and often innovative role. So, the mediator's role is not just after he heard the parties to bring a decision on criminal case which would be obligatory for conflicting parties, but his role is to bring parties' attitudes together and offer a solution which would be acceptable to both parties. If one of the parties is not satisfied, then the issue cannot be solved.

\subsection{Mediation-mediator's rules and skills}

Under the law on mediation-mediator, this procedure is based on the principle of free will of conflicting parties. (Law on mediation in Macedonia,for the first time was approved on 15 May 2006, Official Gazette, No.60). This law originally refers to civil disputes, but it also makes possible resolving of criminal cases in this procedure, especially criminal offenses committed by minors. As for criminal cases, the law does not define what criminal offences can be resolved in the mediation procedure, but only takes into consideration punishment that can be given for that offense, (up to 5 years). Many authors (Vinter, R., Baćanovic, O., Ristanovic, N., (2011), Maloletnicka Pravda, Skopje), think that the mediation procedure cannot be applied in cases where the offender has committed a crime with serious consequences and the way it was committed is very cruel. Then, if it is about an offender (juvenile), who is a recidivist and during modus operandi has been ruthless. This procedure should also not be applied, if the minor with his actions caused damage to more citizens.

\subsubsection{Conditions for the start of mediation procedure}

To begin the mediation procedure, first of all it is necessary for both parties to agree to resolve their dispute informally, in the presence of the mediator. The mediator can be selected from the list of mediators that appears on the website of the Ministry of Justice. This consent consists in that, that the parties agree and give a written consent for the mediation procedure, when comes in question the principle of free will to solve the dispute. If such consent is given by the parties after the criminal proceedings have been initiated, than the decision is made by the public prosecutor or in some cases the juvenile court judge, until the end of the trial. In cases when the parties decide for the criminal case of the criminal procedure to be solved in a mediation procedure, then the consent should be given within 3 days and the mediation procedure cannot last more than 45 days. 


\subsubsection{Mediator's ethics and behavior}

The attitude of the mediator during the solving of the dispute is extremely important. The mediator is a citizen who doesn't wear any kind of uniform, looks friendly and is very serious. The mediator would be successful if at the beginning of the procedure would persuade the parties that their motto is to solve the problem, not to attack each other. So they must be convinced that their presence in this scene is to find an acceptable mode of solving the dispute and that their orientation has a happier future without problems. The parties must understand that the past and perseverance without tolerance bring major damage and loss of precious time. During the proceedings, the mediator should be very careful with his attitude towards the parties. In no way he should leave the impression that he is on the side of one party, he must be unbiased, have a completely neutral attitude, be objective and respect the dignity of the parties. In this regard, the mediator must be careful where to sit, it is not good to sit close to one of the parties, while the other party remains away. The other side will start to feel inferior and unequal, so the mediator must be careful to always sit in the middle of the table, which shows its neutrality towards the parties. The mediator during this period must have a stable attitude, be serious, it is not preferable to embraced one of the parties, clap hands, laugh, while he gives no importance to the other party at all. He also should follow the movements of the parties with great attention, especially facial expressions, pantomimes and gesticulations through which is shown strife and nervousness.(Workshop held in Ohrid, organized by the Chamber of Mediator of the Republic of Macedonia, 2011. Lecturer at the seminar were mediators from the US, Norway etc.)

The mediator should not show feelings and emotions during the proceedings or be impatient, but he should be very calm and not show signs of nervousness. Certainly, to achieve good results, the mediator, should enjoy the authority to parties, so he must be shaved, brushed good, shaved, dressed in costume acceptable, not with sandals and Bermuda. It is also very important mediator notified the issue in detail, it is not good to start the procedure without being familiar with the dispute between the parties in these cases has great chances that the procedure ends unsuccessfully. Once the mediator opens the mediation procedure, initially greeted parties (You, sir, madam, etc.), and gives equal time for conversation (eg 5-10 min) should not be allowed that one party to talk more. Certainly, in order to achieve good results, the mediator should enjoy the authority of both parties, so he must be shorn, brushed, shaved, and dressed up in a costume, not wearing sandals and shorts. It is also very important for the mediator to be acknowledged with the issue in detail, it is not good to start the procedure without being familiar with the dispute between the parties, because in these cases the chances for the procedure to end unsuccessfully are great. Once the mediator opens the mediation procedure, he greets the parties (You, sir, madam, etc.), repeatedly and gives the parties equal time for discussion (e.g. 5-10 min) and it should not be allowed for one party to discuss longer than the other. In this case, the parties are warned that they will not be allowed to say any rude words, insult or humiliation. During the discussions, both sides should be heard carefully, it is not good for either party to get the impression as their discussions and positions were irrelevant. But the mediator gets an important question posed of who should start the discussion or who should have the word first? There are not many rules since the parties are equal, but if you notice that one of the parties is very nervous, impatient then the discussion should be started with that party, in order to soften its attitude and increase the tolerance. If the situation between the parties is very tense, then the mediation procedure can be developed separately, in two different rooms. This procedure can take place even if the dispute is between two groups, hence engage more mediators. In addition, the correct behavior of the mediator will make parties confident, which is an important condition for successful completion of this procedure. From practice, we noticed that when the mediation procedure ends successfully, the contacts between the mediator and the parties continue to evolve even in private life.

\subsubsection{Benefits from mediation procedure}

In our society, there are still many people who persistently wish to realize their rights in court. They believe and are convinced that justice is on their side. But everyone knows how tedious judicial procedures are. Indeed, there are cases where the court proceedings were held for years even for simple cases. During this period the parties lose the valuable time, going through hearings, living under stress, with fights, bitterness, are disappointed by the court tedious procedures, many financial costs and in the end, regardless of the decision of the court, both sides go through nerve-wracking process. In formal-judicial proceedings, the parties do not feel free in the presence of the judge and during the proceedings, since they have no right to communicate freely and easily, but are limited by rigid rules of law. Then the judge, during the proceedings, is limited within his purview, he can't contact them separately and talk about their worries and problems, but sits in the distance as a state official and must adhere to strict procedural rules. Proceedings are 
conducted among more actors (judges, prosecutors, experts, lawyers, offenders, victims, etc.) that automatically make this procedure more complex. Despite all this, the procedure at the mediator is much more comfortable, easier and more efficient. The mediation procedure doesn't return in the past and be based on analysis of the facts and circumstances that occurred earlier, as is the case with court proceedings, this procedure gives importance to the future and focuses on solving the problem without many fatigues. Normally, the mediation is possible only if there is tolerance and compromise between the parties, so this procedure doesn't endure hard principles, but it's flexible, bringing great benefit to both parties involved. This procedure is hidden to the public, but it is more transparent for both disputing parties. In this procedure are present only the parties, (they may engage a defense), and mediator, who has a very low cost, compared to the court proceedings. Here the parties have a very active role, they are the dominant figures, and the mediator doesn't put any kind of pressure on the parties, they themselves propose solving modalities for the case and also are free in decision making. So we can say that this procedure and the resolution of the dispute is in the hands of the parties, the mediator and his technique must create a friendly climate and bring their positions close to each one. Of course, the mediator must not forget and be aware of his role, which extends to assistance, not to try and make a decision on the issue as an arbitrator. From the practice we noticed that the issues that have received positive outcome have been resolved within 2-3 hours, but in the first 15 minutes we have the impression that the parties have positive energy to solve the problem. Indeed it is difficult to define what restorative justice is, so therefore, we will continue with some examples (cases) and will try to show what not a restorative justice is.

Case 1 - Agim stole a mobile phone from his neighbor! But later the case was solved and after a raid, the stolen phone was found at Agim's place. Let's suppose that he was asked to return the cell phone and apologize to the neighbor. Agim turned the phone in and apologized, but certainly would have thought: "Hmm, it was so easy, I lost nothing". In this case, Agim did not understand the severity of the effect he caused, so the possibility to continue to steal and do other criminal acts, are great. Well, this is not a restorative justice.

Case 2 - A quarrel between Agim and Ardian happens, both high school students. Agim is stronger, and he suddenly punches Ardian, causing him serious injuries by breaking his jaw. The school principal is of the opinion that this is a typical behavior for their age, therefore thinks that it is not appropriate to take disciplinary measures against the offender. In this case the director calls the police just to frighten Agim, and in this case the police didn't take any actions against him. Such behavior is not in the interest of the offender, nor in the interest of the victim. The victim receives no compensation, and the offender doesn't understand the importance of the effect he has caused. And it certainly is not a restorative justice.

Case 3 - Agim is married to Mirushe. But he consistently had used domestic violence against her, and with his cruel behavior, often caused severe distress to her. Therefore, after a long period, Mirushe had decided to divorce Agim. During the mediation process, Mirushe was summoned, but she persistently refuses to meet with the offender and is quite unwilling to take part in the proceedings, saying that others let decide on the issue as they wish. Even this is not a restorative justice, because the victim should decide on the compensation of damage by herself.

Case 4 - Agim has committed the offense of fraud. The court has carried out the proceedings, and has decided to determine educational measures against the offender. So, the judge solved the dispute quickly and effectively. The measure might be in the interest of the parties, but still it is not a restorative justice, because the parties did not have any influence on the decision.

In all the above mentioned cases, the role and function of the community was not mentioned at all, which is restorative justice's primary right, because after the offense was committed, the society is a victim, too.

\section{Conclusion}

Of all forms of dispute resolution, the mediation procedure is the easiest and the most efficient. This procedure is proposed as an alternative to court proceedings and indeed in some cases has given proper success. Traditional criminal procedure, in its focus has predominantly the retributive justice character and on its spotlight is the state. In this procedure the offender and the victim have a secondary role during the proceedings and their role is very passive. Unlike this, the restorative justice focuses its importance on the offender and the victim who have a primary role in conflict resolution. This right allows all those affected by the offense, to have an active role in solving the dispute (the victim, offender and society), who are oriented towards the repayment of the consequences to the community and compensation for damage. It is interesting that this right gives the right to the offender to participate actively in conflict resolution and accept his responsibility before the victim and the community. This procedure is not based on arguments of the guilt of the perpetrator and sentencing (vengeful character), but in resolving the conflict with the consent of both parties. 
Especially it would be very positive that this procedure be developed to minors, but also in other cases and provided legal provisions that this procedure would make it mandatory, not only as an alternative to court proceedings. To date, the resolution of disputes in this way is much less present, especially in our population, as they still are focused on the court and are not willing to compromise and tolerance. It would be good in the future police officers to educate the parties to present to guide them to solve it to the mediator. In some cases it is best to self police officers take the role of mediator and settle disputes without taking the case to the court of justice.

\section{References}

Bacanovic, O., (2009). Restorativna Pravda i Zakon za maloletnicka Pravda sa posebnim osvrtom za medijaciju, association of criminal law and criminal policy, no.1, Kotor,;

Kostic, M., (2007),Uspostavljanje standard za restorativnu pravdu, Termida, Belgrade;

Kambovski, V., (2005), Kazneno praven tretman na maloletnite storiteli, UNICEF, Skopje;

Ćopic, S., (2007),Pojam i osnovni principi restorativne pravde, Temida, Beograd, ;

Nikolic-Ristanovic, (2005), V., Restorativna Pravda, compilation of papers, Annals of law faculty, Belgrade;

Elena, A., (2009), Decata vo sudir so zakonot, Shkup;

Renata, V., (2009), Restorativna Pravda, scientific magazine, Maloletnicka Pravda, Skopje. 